\title{
THE ESTABLISHMENT OF A NURSERY SCHOOL FOR MENTALLY HANDICAPPED CHILDREN
}

\author{
Lieutenant-Colonel T. B. STEPHENS, \\ B.Sc., M.B., M.R.C.P., D.P.M., D.T.M.\&H., R.A.M.C. \\ MARGARET N. HANNON, B.S.N., M.S., C.A.G.E. * \\ Headquarters, B.A.O.R.
}

MICHAEL, aged 3 years 11 months, was referred to the Child Guidance Clinic at Mönchengladbach on 7 August 1969 with the statement that he is a mongoloid child and that " the parents find it difficult to cope ". Advice was sought " in respect of a residential school or similar establishment". It transpired that Michael has a severely subnormal intellectual level with an IQ somewhere about 40 or 50 . He showed many of the features of mongolism including the susceptibility of respiratory infections and the allegedly typical restlessness. The parents were very fond of him but barely able to cope and the mother, in particular, found the constant attention to his needs exhausting and limiting.

The opinion " in respect of a residential school "was not difficult to reach; Michael needed professional teaching help and to mix with his peers under supervision. The trouble was that no such facility existed in B.A.O.R. For that matter it would be difficult even in the United Kingdom (U.K.) and although there might be a better prospect of help from various social helping agencies at home there was really little point in returning the family to U.K. There were also the facts that Michael's father has a career to think of and had obligations to the Service, both of which required him to be in Germany.

While we were unaware of any facilities in B.A.O.R. to meet the pressing needs of Michael's family we were only too well aware of a number of similar families who were waiting, more or less patiently, for their names to reach the tops of the long waiting lists for appropriate special schools or training centres in U.K. Parents experience great subjective satisfaction when their children go to school and in developed Western cultures this is a matter of course. When the child is mentally retarded the chances are less and are variable and the parents of mentally handicapped children tend to be fearful that their offspring will eventually drift into subnormality hospitals. (Younghusband et al 1970). The ideal is that each child should have help and education according to his needs. This is unrealistic now but the opposite extreme of ignoring the problem has occurred all too often. Increased consciousness of the needs of the mentally retarded and their families is leading to increased help for them and to the retention of a greater proportion in the community.

At the time we first saw Michael there were 11- school age children of Royal Air Force fathers and about 20 of Army fathers ascertained as mentally retarded and living in the Rheindahlen area. In addition there were an unknown number of pre-school children of similar type. Not all of these were so severely handicapped as to require constant attention to physical needs and protection from common physical dangers but subsequent events have shown that we can expect as many as 10 children to be

\footnotetext{
* Now at Child Evaluation Centre, University of Louisville Medical School, Kentucky, U.S.A.
} 
more or less constantly in need of help in this way. These figures are surprisingly high but it is well known that a large majority of children ascertained as handicapped are so because of mental retardation. In 1967, of the children on the handicapped children's register of the Army Institute of Education, 48.9 per cent were educationally subnormal and a further 21.7 per cent severely abnormal making an absolute total of 506. (Archer 1969).

It seemed likely therefore that the creation of a method of accommodating and training Michael would soon result in an apparent expansion of the demand for such a facility. This has proved to be the case.

The first move was the presentation of a proposal, for what was then seen as a creche or nursery school, to the Rheindahlen Inter Church Senate. It was thought that the aim should be limited to merely caring for the children physically while the mothers had a few hours of freedom for shopping or resting but it soon became apparent that this view was too modest and that a number of people with the special skills for training and caring for these children were available and willing to help. A committee was set out and given the following brief:-

$a$. It is essential that, at least initially, a Trained Worker in this field is present at each Creche Session.

$b$. The Creche Sessions should not exceed two hours-possibly Tuesday and Friday of each week, to be expanded ideally to 3 mornings a week.

c. Helpers required -1 per child, therefore a minimum of 6 allocated to each session to allow for sickness and leave or absence.

$d$. The scheme must be limited to officially ascertained children otherwise it might become too large to control.

$e$. The question of difficulties of transport must be explored together with the area it is proposed to cover.

$f$. A careful selection of location must be made considering especially the type of flooring and the question of cleaning up after Session-many of these children are incontinent. The problem of Insurance is of vital importance and this must be definitely arranged before the Creche is allowed to commence.

g. Finance-the Churches may be able to make initial loans. There is a good deal of goodwill for such projects in the area and fund raising should not prove difficult.

$h$. A careful study must be made regarding the future continuity of this project. It would be fatal to start it if there is any danger of it having to cease through lack of trained staff, helpers, or from any other reasons.

The Committee decided that the project should not be launched until a sum of 1000 DM (£115) had been collected and sufficient helpers were available to provide safe cover for the children. Twenty-nine volunteers, possessing a wide variety of relevant skills, came forward at once and have remained faithful and $3100 \mathrm{DM}(£ 350)$ were collected within one month of opening the account. The school opened on 25 November 1969 and came to be known as the Rheindahlen School for Mentally' Handicapped Children. Initial appointments included Margaret Hannon as the Executive Head and T. B. Stephens to provide advice on enrolment and management of the medical problems of the children. It was decided at the outset that all children should have been assessed 
at the Rheindahlen Child Guidance Clinic before being enrolled in the school but this was soon shown to be insufficient. It is necessary, in our opinion at least, for each child to be assessed with a view to enrolment. This was brought home to us by the case of Carol, aged 9, who had been assessed as severely abnormal but who was also suffering from coeliac disease and maintained on a gluten-free diet. The school were not forewarned of the dangers of her liking for the nice wheaten biscuits, kindly provided at the school, but denied her by her parents. Relapse did not occur in fact, but this brought home the point that severely handicapped children are frequently multiply handicapped children and their physical disorders must be considered.

The brief in respect of the number of adults (teacher or helper) per child was found, after one term, to be inaccurate. It was found that this individual attention was not only not necessary but even disruptive in some cases. A ratio of one adult to every three children became our standard, with a minimum of two adults present for any group no matter how small the total number of children. The age and behaviour characteristics of the children are the best determining criteria for the ratio of adults to children.

Before the school could actually begin holding sessions, a proper facility and furniture of the right size for the children was needed. The requirement was for a large, well ventilated room, free from any dangerous objects and with access to running water and lavatory facilities. Special liability insurance covering the children and workers was required and was obtained. The community room at a local church was offered. Furniture was available and could easily be set up on school days. The room met the minimum requirements and was used for the first term.

At the beginning of the second term, a more permanent and adequate facility was made available in the form of a classroom at one of the primary schools. This classroom was equipped with furniture and lavatory facilities properly scaled for small children and provided direct access to a large outside play area and the wide corridor, adjoining the classroom, afforded an inside play area:

Before the child is finally accepted, an evaluation is made by the headteacher. A visit is made to the home to become acquainted with the parents and to see how the child behaves in his familiar surroundings. From this visit, the teacher can learn more specifics about the child, such as, at what level the child is functioning, what he has accomplished in the areas of social and self help skills, his personality, and how the parents feel about the fact that the child is mentally retarded. This will be most beneficial in her subsequent visits after the child enters the school. The visit is also important because the parents need to know what the school is trying to do for them and the child. If evaluation from the home visit is determined to be acceptable, the child is then evaluated against the following criteria. The child must be trained for control of bowels and be able to stay dry most of the time. The child who is not toilet trained is not refused admission solely on this ground, however. The child must be able to bear his own weight and walk with a minimum of help. No specific age range has been set up for the school. Rather, each child is considered individually as regards his physical size, mental age, behaviour, and self help skills in relation to the other children already enrolled in the school. Our present enrolment ranges in age from 3 years and 6 months to 9 years of age.

The school has the same value for the retarded child as does any nursery school for the normal child. It builds on what the child has already learned in his home. 
Primarily the value of the school experience lies in the opportunity to learn to get along with other children, to participate in organised play activities, and to learn to follow directions given to the group. Emphasis is given to developing self help skills such as feeding at snack time, care of belongings, dressing, and other personal activities. It often happens that when these things are taught or emphasised to the group, the more advanced children find it a rewarding experience to teach the younger or slower child. Learning experiences for the children are presented in the form of music, specific play activities, artwork, and by giving the children opportunities to express themselves freely within the group. Following a set routine each day in school provides consistency and a better feeling of security for the children. Language stimulation is emphasised in all activities.

A wide variation is found in the conditions of the seven children at present attending the school. All are severely sub normal or, at best, in the lower range of E.S.N. One is brain damaged and considered "spastic", one has coeliac disease, one had hydrocephalus with hemiplegia, one is emotionally disturbed, one has Lowe's syndrome and two have Downs syndrome.

Although progress is admittedly slow with these children, definite improvement can be seen. Much of the benefit the children have gained from the School has been furthered by continuing the learning process at home. This was primarily accomplished by several home visits by the head teacher during the two terms the school has run so far in which a sharing of information, regarding progress and failure, was made. This sharing of information helps in better understanding of the child by his parents, in managing the child at home and in the classroom, and should result in happier life both for the child and his family.

\section{Discussion}

The existence of the problem of the retarded child is not new to anybody. What this paper offers is the information that an efficient and effective method of helping such children and their families can be set up in a military community using voluntary contributions of money and skill. It was a revelation to us to find how much of both is available.

Since the need for this type of school existed at Rheindahlen Garrison, it seems logical to assume that the need exists in many other military communities. The resources required to initiate a project of this type are not great. All that is required is a sincere interest and the perseverance to see it through. The mentally handicapped are beginning to find a place in our society. Since the retarded have begun to remain in the community, their status has increased and thus they have become less threatening members of the society. But, by the very nature of their handicap, they will always need an extra degree of individual help. Their health, growth and happiness will always depend on the special interest, knowledge and skills of persons in the medical, psychological and educational fields. 